Review

\title{
Salivary Secretory Disorders, Inducing Drugs, and Clinical Management
}

\author{
Jaume Miranda-Rius ${ }^{\circledR}{ }^{\bowtie}$, Lluís Brunet-Llobet², Eduard Lahor-Soler ${ }^{1}$, Magí Farré ${ }^{3}$ \\ 1. Departament d'Odontostomatologia. Facultat d'Odontologia. Universitat de Barcelona, Barcelona, Spain \\ 2. Servei d'Odontologia. Hospital Sant Joan de Déu. Universitat de Barcelona, Barcelona, Spain \\ 3. Clinical Pharmacology Unit. Hospital Universitari Germans Trias i Pujol-IGTP and Hospital del Mar Medical Research Institute (IMIM). Facultat de Me- \\ dicina. Universitat Autònoma de Barcelona, Barcelona, Spain \\ $\square$ Corresponding author: Jaume Miranda-Rius, MD, DDS, PhD, Departament d'Odontostomatologia, Facultat d'Odontologia, Universitat de Barcelona, Feixa \\ Llarga, s/n, 08907 L’Hospitalet de Llobregat, Barcelona, Spain. Tel: +34 934024 276; Fax: +34 934035 558; e-mail: jmiranda-rius@ub.edu
}

() 2015 Ivyspring International Publisher. Reproduction is permitted for personal, noncommercial use, provided that the article is in whole, unmodified, and properly cited. See http://ivyspring.com/terms for terms and conditions.

Received: 2015.06.09; Accepted: 2015.09.02; Published: 2015.09.22

\begin{abstract}
Background: Salivary secretory disorders can be the result of a wide range of factors. Their prevalence and negative effects on the patient's quality of life oblige the clinician to confront the issue.

Aim: To review the salivary secretory disorders, inducing drugs and their clinical management.

Methods: In this article, a literature search of these dysfunctions was conducted with the assistance of a research librarian in the MEDLINE/PubMed Database.

Results: Xerostomia, or dry mouth syndrome, can be caused by medication, systemic diseases such as Sjögren's Syndrome, glandular pathologies, and radiotherapy of the head and neck. Treatment of dry mouth is aimed at both minimizing its symptoms and preventing oral complications with the employment of sialogogues and topical acting substances. Sialorrhea and drooling, are mainly due to medication or neurological systemic disease. There are various therapeutic, pharmacologic, and surgical alternatives for its management. The pharmacology of most of the substances employed for the treatment of salivary disorders is well-known. Nevertheless, in some cases a significant improvement in salivary function has not been observed after their administration.

Conclusion: At present, there are numerous frequently prescribed drugs whose unwanted effects include some kind of salivary disorder. In addition, the differing pathologic mechanisms, and the great variety of existing treatments hinder the clinical management of these patients.

The authors have designed an algorithm to facilitate the decision making process when physicians, oral surgeons, or dentists face these salivary dysfunctions.
\end{abstract}

Key words: Saliva, Drugs, Xerostomia, Sialorrhea, Drooling

\section{Introduction}

Saliva is an aqueous, hypotonic solution which protects all the tissues of the oral cavity. It is secreted by the major salivary glands - the parotid, submandibular or submaxillary, and sublingual. In the oral cavity there are also a large number of minor salivary glands found on the surfaces of the buccal, palatine, and labial mucosa, as in the tongue, sub-lingual area, and in the retromolar region [1].

The salivary gland structure is made up of acinar cells, accessory ducts (intercalated and intralobular), striated ducts, and the principal duct (Stensen, Wharton, Bartholin, and Rivinus) [1].

Both afferent and efferent stimuli modulate neural control of salivation. Apart from taste and mastication, which play a key role, the former also include smell, sight, and thought. Input to the solitary nucleus from afferent stimuli is integrated via the facial (VII) and glossopharyngeal (IX) nerves [2-4].

Parasympathetic efferent pathways for the sublingual and submandibular glands are from the facial 
nerve via the submandibular ganglion; and for the parotid gland from the glossopharyngeal nerve via the otic ganglion. The parasympathetic nervous system, through the liberation of acetylcholine, acts upon the muscarinic M3 receptors and produces an abundant secretion of aqueous saliva. Sympathetic post-ganglionic pathways are from the cervical ganglion of the sympathetic chain. Stimulation of the sympathetic nervous system by the binding of norepinephrine to $\beta$-adrenergic receptors produces a thicker and less abundant secretion [1,4-6].

Saliva formation and secretion is considered to be a two-step process [1,7]:

Stage 1. Secretion of the isotonic plasma-like primary saliva fluid takes place in the secretory endpieces, also called acinar cells. There is a functional coupling mechanism between salt and fluid secretory processes. Ion channels and transporters promote a vectorial ion transport in the secretory direction from the serosal (basolateral) to luminal (apical) side. Water movement in the salivary glands requires the transcellular secretion of $\mathrm{Cl}^{-}$. The $\mathrm{Cl}^{-}$transporting proteins expressed at the basolateral membrane must, therefore, accumulate $\mathrm{Cl}$ at a quantity superior to its equilibrium potential.

Stage 2. The NaCl-rich fluid is modified during its passage along the duct system, where most of the $\mathrm{NaCl}$ is reabsorbed. The $\mathrm{K}^{+}$concentration in saliva is higher than that found in plasma due to $\mathrm{KHCO}_{3}$ secretion. The final saliva is usually hypotonic because the ductal epithelium is poorly permeable to water and, moreover, $\mathrm{NaCl}$ reabsorption is greater than $\mathrm{KHCO}_{3}$ secretion.

Saliva is primarily made up of water (99\%) and a number of electrolytes which include sodium, potassium, calcium, magnesium, bicarbonate, and phosphate. In addition, there are organic components: immunoglobulins (IgA, IgG, IgM), proteins, enzymes, mucins, and nitrogenized products (urea and ammonium). The $\mathrm{pH}$ values of this biological fluid basically vary from 6 to 7 . Whilst saliva is initially isotonic, during its ductal trajectory it becomes hypotonic. We can distinguish between glandular saliva, which comes directly from a gland, and total saliva or oral fluid, glandular saliva with contaminating elements from the mouth itself $[1,5,8,9]$. The latter has an effect on the oral cavity structures and plays a role in digestion (Table 1) $[8,10]$.

The major glands are primarily responsible for salivary volume and electrolyte content; the minor ones produce a smaller quantity with a high content of substances from the ABO blood group, neutrophils and other leukocytes [8]. Over $90 \%$ of unstimulated salivary secretion is produced by the major salivary glands: $20 \%$ from the parotid glands, $65 \%$ from the submandibular ones, $7-8 \%$ from the sublingual ones, and approximately $10 \%$ from the minor salivary glands. With stimulated saliva the percentages differ considerably, the parotid glands being responsible for more than $50 \%$ of secreted saliva [8].

Table 1: Saliva composition and functions: Relations and roles among the various salivary constituents.

\begin{tabular}{|c|c|c|}
\hline $\begin{array}{l}\text { INFLUENCED } \\
\text { AREAS }\end{array}$ & FUNCTIONS & $\begin{array}{l}\text { SALIVARY } \\
\text { CONSTITUENTS }\end{array}$ \\
\hline \multirow[t]{4}{*}{ Teeth } & Inhibition of demineralization & Mucins \\
\hline & Remineralization / Buffering & $\begin{array}{l}\text { Proline-rich proteins } \\
\text { Statherin } \\
\text { Calcium } \\
\text { Bicarbonate } \\
\text { Phosphate } \\
\text { Proteins }\end{array}$ \\
\hline & Lubrication, viscoelasticity & $\begin{array}{l}\text { Proline-rich glycoprotein } \\
\text { Mucins }\end{array}$ \\
\hline & Digestion & $\begin{array}{l}\text { Amylase } \\
\text { DNAse, RNAse } \\
\text { Lipase } \\
\text { Protease }\end{array}$ \\
\hline \multirow[t]{3}{*}{ Food } & Taste & Zinc \\
\hline & Bolus & Mucins \\
\hline & Antiviral & $\begin{array}{l}\text { Mucins } \\
\text { Immunoglobulins } \\
\text { Cystatins }\end{array}$ \\
\hline \multirow[t]{2}{*}{ Microbes } & Antifungal & $\begin{array}{l}\text { Immunoglobulins } \\
\text { Mucins } \\
\text { Histatins }\end{array}$ \\
\hline & Antibacterial & $\begin{array}{l}\text { Mucins } \\
\text { Lysozyme } \\
\text { Lactoferrin } \\
\text { Lactoperoxidase } \\
\text { Histatin } \\
\text { Agglutinin } \\
\text { Cystatins } \\
\text { VEGh }\end{array}$ \\
\hline
\end{tabular}

There is a wide inter-individual variation of salivary fluid rates. Values of 0.3 to $0.5 \mathrm{ml} / \mathrm{min}$ are considered normal for unstimulated salivary flow; and values between 0.01 and $0.1 \mathrm{ml} / \mathrm{min}$ are considered hyposalivation. Stimulated salivary flow is considered normal when values are from 1 to $2 \mathrm{ml} / \mathrm{min} ;<0.7$ $\mathrm{ml} / \mathrm{min}$ is considered reduced [11]. Average daily saliva flow is from 0.81 to $1.51[1,8]$.

Sialometry encompasses a range of diagnostic tests aimed at evaluating the rate of salivary secretion (quantitative sialometry) and analyzing its composition (qualitative sialometry). When quantitative sialometry is employed it should be specified whether the saliva is mixed or uni-glandular, and whether the figures have been obtained at unstimulated state or after stimulating the secretion. Endogenous and exogenous salivary constituents are determined through qualitative sialometry: the former to assess physiological states and diagnose salivary gland diseases and systemic metabolopathies, and the latter to confirm treatment compliance and intoxication [12].

Salivary secretory disorders, xerostomia and sialorrhea, can be caused by a wide range of factors 
including drugs [8].

Xerostomia is the term used for the subjective sensation of dry mouth. This syndrome is a combination of signs and symptoms associated with a decrease in the secretion of saliva [13-15]. The reported prevalence of xerostomia ranges from $17-29 \%$, and in a recent cross-sectional study approximately $20 \%$ was observed. Women have a significantly higher rate than men. The most frequent causes of dry mouth among dental patients are the use of xerogenic medications, head and neck radiotherapy, and Sjögren syndrome. It is generally accepted that xerostomia results in a lower quality of life for all affected patients [15-18].

Sialorrhea is a salivary hyper-secretion clinically diagnosed by quantitative sialometry. Drooling in many cases is not accompanied by an increased salivary flow, generally the flow of saliva is normal or reduced and only the handling of saliva is disturbed. However, some drooling in infants and toddlers is normal and it may occur with teething [14-19].

To the best of our knowledge, there are no data concerning sialorrhea prevalence rates in the literature. However, some authors have reported a drooling prevalence of approximately $14 \%$ in their control group, and $56 \%$ in the Parkinson's disease one. In children with cerebral palsy the range of drooling prevalence was between 45-58\% [20-23].

The objectives of the present review were:

1- Study different causes of xerostomia, sialorrhea and drooling.

2- Review the most important drug-effects involved in these disorders.

3- Provide a clinical approach to the current management strategies for these entities.

\section{Methods}

A literature search was conducted with the assistance of a research librarian in the MEDLINE/PubMed Database. The primary outcome was to identify all literature containing original and review data describing (a) causes of xerostomia, sialorrhea and drooling, (b) the drugs related with xerostomia, sialorrhea and drooling, and (c) management strategies of these salivary gland disorders.

The following terms were covered in the search were covered the terms: xerostomia $(\mathrm{MeSH})$, sialorrhea (MeSH), drooling (MeSH), and "AND" - combined with terms: "causes", "ethiology", "drugs", "drug induced", "Sjögren's syndrome", "head and neck radiation", "management", "therapy", "bioengineering" (MeSH).

\section{Selection of studies}

The selection of qualified studies was performed in three stages. First stage: assessment of the title alone. Second stage: based on the abstract, they were reviewed and irrelevant citations were removed. Third stage: selection based on the review of full-text article. The selected articles were distributed to the reviewer team along with a customized evaluation form for reviewing xerostomia, sialorrhea and drooling.

\section{Xerostomia}

This disorder may be caused by medication, systemic diseases, pathologies of the salivary glands, and head and neck radiotherapy (Table 2) [15-24].

\section{Drug induced xerostomia}

From an etiological perspective, xerostomia is most frequently associated with medication. It is the side effect of a large number of drugs and $70 \%$ of adults taking some kind of medication can suffer from it [24].

Anticholinergic and antimuscarinic agents are drugs with the capacity to reduce or block the effects produced by acetylcholine on the central and peripheral nervous system. They are generally competitive reversible antagonists of some of the two types of acetylcholine receptors, and are classified according to the receptor they block. Most anticholinergic agents affect muscarinic gland receptors producing a decrease in salivary secretion [5].

Antidepressants, such as fluoxetine, with a serotoninergic action have xerostomia as a common side effect. Xerostomia is also observed in other kinds of antidepressants (monoamine-oxidase inhibitors, tricyclics, heterocyclics, and others) and antipsychotics, many of which are anticholinergic agents [5].

Within the group of diuretics the loop and potassium-sparing ones are noteworthy as their target molecules include $\mathrm{Na}^{+}, \mathrm{Cl}^{-}$and $\mathrm{K}^{+}$, electrolytes present in the production-secretion process of saliva $[15,25,26]$.

Table 2: Main causes underlying xerostomia.

\begin{tabular}{ll}
\hline Drugs & See table 3 \\
Systemic diseases & $\begin{array}{l}\text { Sjögren's syndrome (primary and secondary) } \\
\text { Granulomatous diseases (sarcoidosis, tuberculosis) } \\
\text { Graft-versus-host disease } \\
\text { Bone marrow transplantation } \\
\text { Renal dialysis } \\
\text { Malnutrition (anorexia, bulimia, dehydration) }\end{array}$ \\
& $\begin{array}{l}\text { External beam radiation } \\
\text { Radiation and } \\
\text { radioisotopes }\end{array}$ \\
& $\begin{array}{l}\text { Radioactive iodine (I-131) } \\
\text { Head and neck radiation }\end{array}$ \\
\hline
\end{tabular}


Table 3: Some drugs known to be associated with drug-induced xerostomia.

\begin{tabular}{|c|c|}
\hline $\begin{array}{l}\text { Anticholinergic/ } \\
\text { antimuscarinic agents }\end{array}$ & $\begin{array}{l}\text { Atropine, belladona, benztropine, oxybutynin, scopola- } \\
\text { mine, trihexyphenidyl }\end{array}$ \\
\hline Diuretic agents & $\begin{array}{l}\text { Chlorotiazide, furosemide, hydrochlorothiazide, triam- } \\
\text { terene }\end{array}$ \\
\hline $\begin{array}{l}\text { Antihipertensive } \\
\text { agents }\end{array}$ & $\begin{array}{l}\text { Captopril, clonidine, clonidine/chlorthalidone, enalapril, } \\
\text { guanfacine, lisinopril, methyldopa }\end{array}$ \\
\hline $\begin{array}{l}\text { Antidepressants and } \\
\text { antipsychotics }\end{array}$ & $\begin{array}{l}\text { Selective serotonin-reuptake inhibitors: citalopram, } \\
\text { fluoxetine, paroxetine, sertraline, venlafaxine } \\
\text { Tricyclic antidepressants: imipramine, amitriptyline, } \\
\text { desipramine, nortriptyline } \\
\text { Monoamine oxidase inhibitors IMAO: phenelzine } \\
\text { Other antidepressants: bupropion, nefazodone, } \\
\text { mirtazapine } \\
\text { Typical (first generation) and atypical (second generation) } \\
\text { antipsychotics: haloperidol, pimozide, clozapine, } \\
\text { olanzapine }\end{array}$ \\
\hline Antihistamines & $\begin{array}{l}\text { Astemizole, brompheniramine, chlorpheniramine, di- } \\
\text { phenhydramine, loratadine, meclizine }\end{array}$ \\
\hline $\begin{array}{l}\text { Sedative and anxiolytic } \\
\text { agents }\end{array}$ & $\begin{array}{l}\text { Alprazolam, diazepam, furazepam, temazepam, tria- } \\
\text { zolam }\end{array}$ \\
\hline Muscle relaxant agents & Cyclobenzaprine, orphenadrine, tizanidine \\
\hline $\begin{array}{l}\text { Opioids analgesic } \\
\text { agents }\end{array}$ & $\begin{array}{l}\text { Central nervous system: codeine, meperidine, metha- } \\
\text { done, pentazocine, propoxyphene, tramadol }\end{array}$ \\
\hline $\begin{array}{l}\text { Nonsteroidal anti- } \\
\text { inflammatory agents }\end{array}$ & Diflunisal, ibuprofen, naproxen, piroxicam \\
\hline Other drugs & $\begin{array}{l}\text { Anorexiants: diethylpropion (amfepramone), sibutramine } \\
\text { Antiacne agents (retinoids): isotretinoin } \\
\text { Anticonvulsants: carbamazepine } \\
\text { Antidysrhythmics: disopyramide } \\
\text { Anti-incontinence agent -anticholinergics-: tolterodine } \\
\text { Antiparkinsonian agents: carbidopa / levodopa } \\
\text { Bronchial dilators-anticholinergics-: ipratropium } \\
\text { Ophthalmic formulations: brimonidine (alpha-2 adrener- } \\
\text { gic agonist) } \\
\text { Smoking cessation agents: nicotine } \\
\text { Adrenergic agents: Amphetamine } \\
\text { Drugs of abuse: MDMA, cannabis }\end{array}$ \\
\hline
\end{tabular}

Antihypertensive drugs such as the inhibitors of the angiotensin-converting enzyme (captopril and enalapril) may cause the accumulation of bradykinin-tissular mediator which is responsible for a large number of adverse reactions. Up to $8 \%$ of patients taking captopril, enalapril, and lisinopril present xerostomia $[27,28]$.

Anxiolytic, sedative, and opiate drugs may provoke xerostomia as a secondary effect in patients who are taking them chronically $[29,32]$.

Some antihistamines, particularly those of the first generation and some of the third, for instance, desloratadine, have an antimuscarinic effect which may lead to xerostomia and sedation. Second and third generation antihistamines effectively antagonize $\mathrm{H} 1$ receptors without any special affinity for the muscarinic receptors $[33,34]$.

A number of non-steroidal analgesic and anti-inflammatory drugs (diflunisal, ibuprofen, naproxen, and piroxicam), anorexigens, anti-acne, anti-parkinsons, and anti-smoking agents amongst others, may cause a decrease in salivary secretion as a secondary effect (Table 3) [35].

Adrenergic agents may induce dry mouth syndrome. Amphetamine and MDMA (also known as ecstasy) can act directly or indirectly on a number of receptors, including the a2-adrenergic one, thus causing xerostomia. Occasionally, this effect may also lead to an acute localized periodontal pathology. Several reported cases of necrotizing ulcerative gingivitis (NUG) have been associated with the consumption of MDMA. The possible mechanism may be due to a direct contact between the drug and the oral mucosa, the acid components of the tablet, and the dry mouth induced by MDMA [36].

Other illicit drugs, for example cannabis, produce short-term hyposalivation due to the action of delta-9-tetrahydrocannabinol (THC) [37].

\section{Xerostomia and Sjögren syndrome}

Sjögren Syndrome (SS) is a multisystem autoimmune disease which causes lymphocytic infiltration in the exocrine glands, particularly the salivary and lacrimal ones leading to the characteristic features of dry eye and salivary dysfunction (xerostomia). In addition, approximately one third of the patients present systemic extraglandular manifestations [38].

Focal lymphocytic sialoadenitis (FLS) of the labial salivary glands (minor glands) has long been associated with SS. Daniels et al. [39,40] observed that the focus score of FLS is strongly associated with the ocular and serologic components of SS and reflects SS autoimmunity.

Broadly accepted classification norms were developed and validated between 1989 and 1996 by the European Study Group on Classification Criteria for SS. The most widely accepted classification criteria for SS are the American-European Consensus Group (AECG) revised version [38]. Recently, the Sjögren's International Collaborative Clinical Alliance (SICCA) published new classification criteria following the American College of Rheumatology guidelines [41]. This consensus criticized the inclusion of subjective tests (symptoms), physiological measures that lack specificity, and alternate objective tests that are not diagnostically equivalent to the AECG classification criteria $[39,41,42]$. However, the final classification criteria might be a mix of the AECG and the SICCA.

\section{Head and neck radiation}

Radiotherapy (RT) of the head and neck region may cause acute side-effects such as mucositis, dysphagia, hoarseness, erythema, and desquamation of the skin $[43,44]$. Later may appear chronic injuries to 
vasculature, salivary glands, mucosa, connective tissue, and bone. The severity of these complications depends on radiation dosimetry, and treatment duration [45].

Xerostomia is the main complication in these irradiated patients as it usually involves a high radiation dose to both salivary gland [46].

Radiation-induced xerostomia has an early onset: in the first week, half the patients present a decrease in salivary flow. After 7 weeks of head and neck RT the salivary flow diminishes up to $20 \%$ [47]. Salivary function continues to decline after RT, and there is minimal long-term recovery [45].

With respect to the mean radiation dose, some authors have indicated that less than 25-35 Gy will probably prevent long-term injury. However, the issue as to whether there is a threshold dose for initiating injury versus a gradual dose-complication remains controversial. After head and neck RT, salivary glands have a limited capacity for repair especially with mean doses above 40 Gy [48].

\section{Sialorrhea and Drooling}

Salivary hypersecretion/sialorrhea and drooling, may be caused by medication, systemic diseases, psychiatric disorders, oral pathologies, and toxic substances (Table 4) [14].

In healthy subjects drugs may increase saliva secretion but usually not result in drooling, the produced saliva can be easily handled. On the other hand, drooling is generally accompanied by insufficient handling of saliva and not by hypersalivation.

\section{Drug-induced sialorrhea and/or drooling}

Direct muscarinic agonists are parasympathomimetic and, therefore, increase cholinergic tone and induce sialorrhea. Pilocarpine, used to treat wide-angle glaucoma, causes salivary hypersecretion as one of its adverse effects. The muscarinic agonist, arecoline, is an alkaloid with parasympathomimetic properties (see also at the end of this section the betel nut comment). Bethanechol is a cholinergic drug that selectively stimulates the parasympathetic nervous system across muscarinic receptors. It is sometimes given orally or subcutaneously to treat urinary retention resulting from a general anesthetic, diabetic neuropathy of the bladder, or to treat gastrointestinal atony (lack of muscular tone). Cevimeline is also a parasympathomimetic and muscarinic agonist with particular effect on $\mathrm{M}_{3}$ receptors [13,49].
Table 4: Main causes underlying drooling or sialorrhea.

\begin{tabular}{|c|c|}
\hline Drugs & See table 5 \\
\hline $\begin{array}{l}\text { Neurological } \\
\text { diseases }\end{array}$ & $\begin{array}{l}\text { Myasthenia gravis } \\
\text { Cerebral palsy } \\
\text { Facial paralysis } \\
\text { Guillain-Barré syndrome } \\
\text { Motor neuron disease, notable amyotrophic lateral sclerosis } \\
\text { (ALS) } \\
\text { Moebius syndrome } \\
\text { Cerebrovascular accidents } \\
\text { Parkinson's disease } \\
\text { Congenital suprabulbar palsy } \\
\text { Hydrocephalus } \\
\text { Hypoxic encephalopathy } \\
\text { Freeman-Sheldon syndrome } \\
\text { Psychosis } \\
\text { Brain tumors } \\
\text { Seizures } \\
\text { Severe mental retardation, Down syndrome } \\
\text { Worster-Drought syndrome } \\
\text { Landau-Kleffner syndrome } \\
\text { Encephalitis } \\
\text { Angleman syndrome }\end{array}$ \\
\hline Systemic diseases & $\begin{array}{l}\text { Nasal obstruction } \\
\text { Heavy metal poisoning } \\
\text { Hyperhydration } \\
\text { Digestive pathologies: } \\
\text { Oesophageal spasms, tumors and ulcerations, gastric disorders } \\
\text { accompanied by nausea and vomiting, pancreatitis, bladder } \\
\text { processes, intestinal infections }\end{array}$ \\
\hline Oral conditions & $\begin{array}{l}\text { Mucosal ulcerations } \\
\text { Teething } \\
\text { Ulcerative lichen planus } \\
\text { Herpetic ulceration } \\
\text { Traumatic ulceration } \\
\text { Oral pain: pulpitis, periodontitis, stomatitis } \\
\text { Pharynx and tonsilar Inflammation, irritative and ulcerative } \\
\text { lesions }\end{array}$ \\
\hline
\end{tabular}

Table 5: Some drugs known to be associated with drug-induced drooling or sialorrhea.

\begin{tabular}{|c|c|}
\hline $\begin{array}{l}\text { Direct cholinergic/ } \\
\text { muscarinic agonists }\end{array}$ & Bethanechol, pilocarpine, arecoline, cevimeline \\
\hline $\begin{array}{l}\text { Indirect cholinergic/ } \\
\text { muscarinic agonists } \\
\text { (acetylcholinesterase } \\
\text { inhibitors) }\end{array}$ & $\begin{array}{l}\text { Edrophonium, neostigmine, physostigmine, pyri- } \\
\text { dostigmine, metrifonate, donepezil, galantamine, } \\
\text { rivastigmine, tacrine }\end{array}$ \\
\hline Antipsychotics & $\begin{array}{l}\text { Typical (first generation) antipsychotics: haloperidol, } \\
\text { fluphenazine } \\
\text { Atypical (second generation) antipsychotics: } \\
\text { clozapine, risperidone, olanzapine } \\
\text { Reserpine }\end{array}$ \\
\hline Sedative medications & $\begin{array}{l}\text { Anticonvulsants-antiepileptics } \\
\text { Benzodiazepines }\end{array}$ \\
\hline $\begin{array}{l}\text { Adrenergic antagonists } \\
\text { (peripheral) }\end{array}$ & Yohimbine \\
\hline $\begin{array}{l}\text { Medications irritating the } \\
\text { esophagus }\end{array}$ & $\begin{array}{l}\text { Doxycycline, tetracycline, iron preparations, quini- } \\
\text { dine, potassium, nonsteroidal anti-inflammatory } \\
\text { drugs }\end{array}$ \\
\hline Poisons and toxins & $\begin{array}{l}\text { Heavy metals: arsenic, manganese, mercury (inor- } \\
\text { ganic volatile), thallium } \\
\text { Organophosphates: insecticides, nerve gases (sarin, } \\
\text { tabun, soman, VX) } \\
\text { Food poisoning: Amanita muscaria } \\
\text { Illicit drugs: phencyclidine (PCP) }\end{array}$ \\
\hline $\begin{array}{l}\text { Herbal and fruit prepara- } \\
\text { tions }\end{array}$ & $\begin{array}{l}\text { Betel nut, jaborandi, yohimbine, citric acid, red } \\
\text { pepper }\end{array}$ \\
\hline
\end{tabular}


Indirect muscarinic stimulants are primarily inhibitors of the acetylcholinesterase enzyme, they increase acetylcholine to stimulate muscarinic and nicotinic receptors which results in an increased saliva flow. Donepezil, galantamine, and rivastigmine, the main clinical acetylcholinesterase inhibitors, are used in the treatment of Alzheimer's disease. Despite its compelling mechanism, drooling is rarely considered to be a clinical problem with this class of drugs [50-52]. Other inhibitors of acetylcholinesterase are edrophonium, neostigmine, and physostigmine, mainly employed in the diagnosis and treatment of myasthenia gravis [53].

Antidopaminergic drugs can all potentially lead to drooling if they cause clinical bradykinesia which results in a low rate of swallowing. This is usually clinically quite evident as patients appear to have extrapyramidal side effects. Antipsychotic drugs can, therefore, produce sialorrhea due to:

1. Induced parkinson symptoms.

2. Blockage of the a2-adrenergic receptors or decrease of noradrenaline.

3. Direct agonism of the M3 and M4 muscarinic receptors.

Typical (first generation) antipsychotic drugs, such as haloperidol and fluphenazine, are stronger inducers for extrapyramidal symptoms than those of the atypical (second generation) antipsychotics, for instance clozapine, risperidone, and olanzapine. Another mechanism that interferes with swallowing is excessive sedation, a side effect of many antipsychotics [13].

Clozapine is the atypical antipsychotic prototype. It can cause sialorrhea due to its agonist effect on the M3 and M4 glandular muscarinic receptors which leads to an increase in salivary secretion through the parasympathetic nervous system, and also because of its antagonism with the a2-adrenergic receptors of the sympathetic nervous system [54,55].

In some cases, benzodiazepines may cause drooling, indicating a change in the underlying swallowing process due to excessive sedation, particularly at high doses [13].

Drooling can also result from an esophagus mucosal inflammation induced by tetracycline, doxycycline, iron preparations, quinidine, potassium, and non-steroidal anti-inflammatory drugs which might impair swallowing either functionally or from pain $[13,14]$.

Drooling is a hallmark of some toxins such as organophosphate insecticides and related nerve agents which irreversibly block the acetylcholinesterase enzyme, thus producing signs and symptoms from the overstimulation of the muscarinic and nicotinic receptors. Pro-cholinergic toxins from mushrooms such as the muscarine (Amanita muscaria) can produce sialorrhea in acute intoxication. Poisoning from mercury, thallium, manganese, and arsenic can also induce drooling [56-60], and it is also a clinical sign of some illicit drugs such as phencyclidine (PCP) [13].

A number of preparations based on herbs, for instance jaborandi which contains pilocarpine, and yohimbine supplements (alkaloids) considered to be peripheral adrenergic a2 antagonists, may stimulate salivary secretion [61,62]. In addition, the betel nut, a widely used drug chewed by millions of people in Southeast Asia, contains arecoline a direct muscarinic agonist which can cause "betel nut drooling", whilst both citric acid and red pepper can stimulate saliva flow (Table 5) [13].

\section{Neurological diseases}

Drooling is often a consequence of some centrally neurological disorders, as in patients affected by cerebral palsy or mental retardation. Nevertheless, there are some peripheral affections such as seventh or ninth cranial nerve palsies where drooling may be also present [63]. Furthermore, Lespargot et al. indicated that drooling is related to one or more of three abnormalities [64]:

- Incomplete lip closure during swallowing.

- Low suction pressure.

- Prolonged delay between the suction and the propulsion phase of the intra-oral, as opposed to the pharyngeal or oesophageal, stage of swallowing.

\section{Management}

\section{Xerostomia}

Xerostomia has clear, negative effects on oral-dental tissue. Some of the best known side effects include demineralization of tooth enamel, rampant decay, super-infections caused by fungal diseases (candidiasis), reactive gingival enlargement due to dehydration, and loss of salivary antimicrobial properties [15]. Xerostomia can also influence ingestion, swallowing, and speech articulation, thus negatively affecting the quality of life of people suffering from it $[65,66]$. Its high prevalence, $17-29 \%$ according to population samples based on salivary flow, makes it advisable that its clinical management be well-known [15]. See the algorithm (Fig 1).

Initial treatment of xerostomia is basically palliative, minimizing symptoms and preventing oral complications $[15,62,66]$.

- The elimination of possible factors for xerostomia such as mouthwashes with an alcoholic content, diet sugar, and toxic habits including alcohol and tobacco. 
- Preventive treatment for complications.

If xerostomia is an unwanted consequence of pharmacological treatment $[67,68]$ :

- The possibility of alternative medication with different mechanism of action should be considered.

- Reduction of the prescribed dosage may, in some cases, increase salivary flow.

- There are a number of varying frequently employed drugs and strategies for the clinical management of these patients: sialogogic drugs, immunologic agents, topical medication, and complementary and alternative medicine $[19,69]$.

\section{Sialogogic drugs}

Sialogogic drugs are substances designed to stimulate salivary secretion as they have an effect on the systemic pathway. These drugs act upon differing receptor groups:

- Direct and indirect muscarinic agonists.

- Peripheral adrenergic a2 antagonists.

- Centrally active agents that diminish adrenergic tone.

Pilocarpine has been shown to be efficient in SS patients, irradiated and with bone marrow transplants. Studies have reported positive results with respect to glandular function and improvement in symptoms [19,69-73]. Pilocarpine dosage is from 5 to $10 \mathrm{mg} 1 \mathrm{~h}$ before eating, 3 times a day oral route (OR). Onset of effects at 30 min with a duration between 2-3 $\mathrm{h}$ [72].

Cevimeline Hydrochloride is indicated for the treatment of dry mouth syndrome in patients with SS. The recommended dosage is $30 \mathrm{mg} 3$ times a day (OR). In theory, cevimeline is more specific when acting on salivary glands and thus presents less severe unwanted effects [19,69,73-75].

Bethanechol chloride has been reported in a number of studies to decrease unwanted effects caused by antidepressant and antipsychotic drugs. It is administered 4 times a day in doses from 10 to 50 $\mathrm{mg}$. It has a $1 \mathrm{~h}$ effect and its onset of action appears 30 min after being administered (OR) [76-78].

Anetholetrithione has been shown in clinical studies to improve symptoms of xerostomia. The habitual dosage is $25 \mathrm{mg} 3$ times a day $[79,80]$.

Other agents have been put forward as sialogogic drugs in spite of a lack of scientific evidence from clinical studies. They include bromhexine and other mucolytic agents such as guaiphenesin. In addition, substances such as herbal preparations, neostigmine, distigmine, yohimbine, nicotinic and malic acid have also been attributed positive effects in the treatment of xerostomia $[19,81]$.

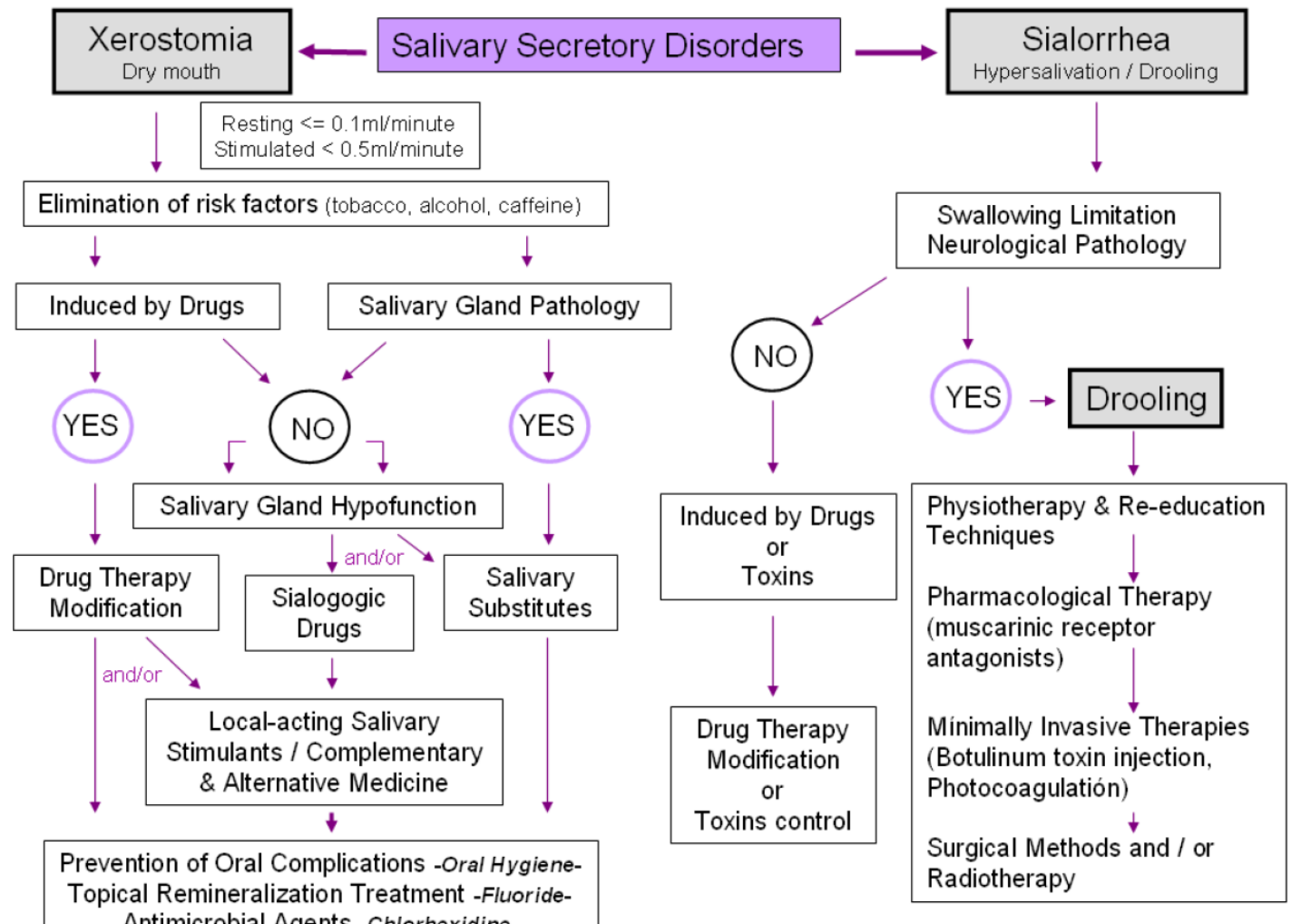

Figure 1. Algorithm of salivary secretory disorder management. 
Amongst the secondary effects produced by cholinergic drugs employed as sialogogics the following are the most noteworthy: gastrointestinal alterations, sweating, bronchospasms, altered heart rate, and blurred vision. Excessive use may produce a contrary effect in some patients, for example sialorrhea and drooling. They are contraindicated or considered to be of risk for patients with bronchial asthma, chronic obstructive pulmonary disease, cardiac disease (angina pectoris, acute myocardial infarction), hyperthyroidism, gastric ulcer, arterial hypertension, risk of intestinal obstruction, or ureteral colic $[19,69,72,78]$.

\section{Immunologic agents and salivary gland protectors}

Biological substances which modulate immunological response; for instance, due to the fact that they aid tissue regeneration of the glandular parenchyma, they are employed in the treatment of tissue autoimmune-related xerostomia [82].

The interferons are proteins involved in a wide range of regulatory functions: cell proliferation and differentiation, enzyme induction, and the antigen expression of the cell surface [83]. Interferon alpha (IFN-a) has been proposed as an effective treatment for autoimmune-related xerostomia, linked to SS, in which the levels of salivary cytokines are altered leading to the destruction of glandular tissue. It could act as a modifier of the biological response thus improving salivary gland function [83-87].

Rituximab is a chimeric murine/human anti-CD20 monoclonal antibody [88,89]. Meijer et al., [90] in pilot trials involving patients with some residual glandular secretory potential, described that rituximab might improve subjective and objective symptoms related to primary SS for at least 6-9 months. These authors observed that no relevant improvement in salivary gland function can be expected in patients with little or no secretory potential at baseline [90]. In the same way, Meiners et al. [91] reported that anti-CD20 therapy can be considered an effective treatment option in primary SS patients. However, Ramos-Casals et al. [92] concluded that larger controlled trials were needed to establish the efficacy of rituximab.

Amifostine is a cytoprotective agent which acts as a free radical scavenger, diminishing the cell damage caused by radiation when administered simultaneously with RT. The benefits are, however, insignificant [48].

Other treatments with dubious reliability and multiple secondary effects for SS-associated xerostomia have been reported in the literature, for instance, anti-tumor necrosis factor alpha therapy (etanercept, abatacept, infliximab, adalimumab, certolizumab pegol, and golimumab), hydroxychloroquine, anti-inflammatory drugs, methotrexate, hormone replacement, and other monoclonal antibodies [19,69,86,93-98].

\section{Topical medication}

Salivary substitutes, local-acting salivary stimulants, lubricants, and protectors. There are a number of distinct products included within this group such as toothpaste, mouthwash, moisturizing gel, chewing gum, and salivary flow stimulating tablets (Table 6).

Table 6: Salivary substitutes, local-acting salivary stimulants, lubricants, and protectors.

\begin{tabular}{ll}
\hline Pharmaceutical & Mouthwash \\
Forms & Toothpaste \\
& Gel \\
& Spray \\
& Capsule \\
& Tablet \\
& Chewing gum \\
Drug & Olive oil, Betaine, Xylitol \\
Combinations & Sorbitol, Xylitol, Betaine, Allantoin, Sodium fluoride \\
& Betaine, Aloe Vera, Xylitol, Sodium fluoride \\
& Malic acid, Xylitol \\
& Malic acid, Xylitol, Sodium fluoride \\
& Triclosan, Sodium fluoride, Aloe Vera, Vitamin E \\
& Sorbitol, Xylitol, Sodium fluoride, Panthenol, Vitamin E \\
& Xylitol, Potassium chloride, calcium, magnesium \\
& Maltitol, Xylitol, Sorbitol, Lysozyme, Lactoferrin, Colostrum \\
& extract, Glucose oxidase, Aloe barbadensis, Minerals \\
& CPP-ACP (Casein Phosphopeptide-Amorphous Calcium Phos- \\
& phate), Fluoride \\
& Lactoferrin, Lactoperoxidase, Lysozyme, Glucose oxidase, So- \\
& dium monofluorophosphate, Fluoride, Xylitol, Aloe Vera \\
& Stannous Fluoride(0.4\% w/w), Glycerine, hydroxyethylcellulose \\
& Sodium fluoride (1.1\% w/w)
\end{tabular}

They are used for the palliative treatment of patients with non-functional glandular parenchyma, many of them affected by SS, and for whom sialogogic therapy is inadequate.

The use of sugar-free chewing gum or tablet can increase salivary secretion and improve the sensation of dry mouth together with gustatory and masticatory stimulation. These products can additionally be fluoride, chlorhexidine, calcium phosphate, and xylitol releasers [99,100]. Simons et al. [101] observed in elderly populations the capacity of chlorhexidine-xylitol releasers, through chewing, to positively modify cariogenic microflora. Toothpastes and gels with high fluoride concentrations have also been introduced in the management of xerostomic patients [102,103].

Salivary substitutes are compounds which generally contain water, electrolytes, glycoproteins, carboxymethylcellulose, hydroxymethylcellulose, mucins, sweetening enzymes, preservatives, and some fluoride products. They are presented as solutions, 
gels, tablets, or spray and administered as many times as needed with the aim of providing a prolonged humidity of the oral mucosa. In European countries, bovine- and porcine-derived mucin-containing substitutes are used, whilst in the United States, substitutes based on carboxymethylcellulose, sometimes accompanied by mucopolysaccharides and glycerol polymer gels, are employed [81,104]. Various authors have studied the sensation of comfort in xerosotomia patients comparing salivary substitutes with placebo, or stimulating salivary secretion with chewing gum $[105,106]$. Ship et al. [107] demonstrated that the use of the novel topical dry mouth products containing olive oil, betaine, and xylitol (Xerostom ${ }^{\circledR}$ products) significantly increased non-stimulated whole salivary flow rates, reduced complaints of xerostomia, and improved xerostomia-associated quality of life.

Stewart et al. [108] evaluated the preference and efficacy of three products indicated to reduce xerostomia: a salivary substitute (with a sorbitol/xylitol base), and two salivary stimulants (sorbitol/xylitol chewing gum and acidic tablets with sorbitol). No significant differences were observed between the sialometry of these products and the control group. Chewing gum, however, appeared to be a greater stimulant and in most cases gave the most relief for dry mouth syndrome.

Intraoral releasers of saliva substitutes - reservoirs. These are intraoral devices designed to deliver a salivary substitute (Oralbalance gel ${ }^{\circledR}, \mathrm{K}-\mathrm{Y}$ jel$1 y^{\circledR}$, Orthana ${ }^{\circledR}$ artificial saliva) for a prolonged period. Patients who habitually wear a dental prosthesis can have them built into the prosthetic structure $[109,110]$. Results from reviewed studies are contradictory and with low rates of success [111,112].

Neuroelectric stimulation. In recent years, non-pharmacological treatment based on electrostimulation has been developed for xerostomia [113]. Through the use of miniature, intraoral electrostimulators with dental splints the increase of salivary secretion and improvement of symptoms have been attempted $[114,115]$. Other electrostimulation systems such as transcutaneous electrical nerve stimulation (TENS) or the remote control Saliwell GenNarino device have shown an increase in salivary secretion in healthy patients $[116,117]$.

\section{Glandular regeneration and surgical methods}

Glandular regeneration. Mechanisms to restore acinar cell function through tissue engineering and genetic therapy have been recently studied $[114,118,119]$. Regenerative therapy involves tissue stem cell transplantation to grow or re-grow healthy organs. Its ultimate goal is to develop fully functioning bioengineered organs to replace lost or damaged organs that result from disease, injury or aging [118-122].

In glandular regeneration, the use of duct stem cells has been reported for salivary gland tissue repair [123]. Ogawa et al. [124] demonstrated the fully functional regeneration of a salivary gland through the orthotopic transplantation of a bioengineered salivary gland germ in adult mice. This recent study provides a proof-of-concept for bioengineered salivary gland regeneration as a potential treatment for xerostomia.

Surgical methods. Some authors have proposed a preventive surgical technique [125-128]. Jha et al. [127] described a submandibular duct transposition to the region below the chin in order to prevent radiation-induced xerostomia in patients with neoplasias of the pharynx and larynx.

\section{Complementary and alternative medicine}

Medicinal herbs, such as jaborandi (which contains pilocarpine), yohimbine supplements (with yohimbine as an active ingredient plus others alkaloids), betel nut (which contains arecholine a muscarinic agonist), citric acid, red pepper, bakumondoto, Iceland Moss (Cetraria islandica), and Longo Vital can all stimulate salivary secretion [129-132].

Acupuncture as a method of treatment has a physiological and psychological effect through the activation of various biological mechanisms [133-135]. There are, however, no randomized clinical trials available which can establish this method based on evidence [68].

\section{Sialorrhea and drooling}

In patients with persistent drooling salivary incontinence may even be accompanied by perioral and/or chin dermatitis, cheilitis and on occasions, they may experience fungal infection. In severe cases of salivary hypersecretion or sialorrhea, muscular fatigue may arise caused by continuous forced swallowing due to excess saliva. Sialorrhea may functionally affect phonation and gustative perception. The pathological repercussions should also be taken into consideration as there is an accompanying loss of liquids, electrolytes, and proteins [13,14,63].

There are a number of distinct therapeutical alternatives which basically differ according to their degree of invasiveness and the administration or not of medication. The following strategies are the most frequently used: physiotherapy and neuromuscular re-education techniques, pharmacological therapy (anticholinergic drugs), complementary and alternative medicine, minimally invasive therapies, radiotherapy, and therapeutical surgery $[13,14]$. See the algorithm (Fig 1). 
Physiotherapy and neuromuscular re-education techniques

Oral motor therapy. Aimed at improving oral skills such as suction, lip closing, and tongue and mandibular mobility. The speech therapist plays a crucial role in the evaluation of existing oral motor skills [14].

Behavioral modification through biofeedback. Biofeedback techniques condition the patient to swallow on hearing auditory stimulation. Such techniques have not yet been implemented in clinical practice $[14,136]$.

Oro-facial regulation therapy. Functional appliances are employed with high success rates. In cases where the disorder is not completely eliminated it is at least reduced. This therapy can be used with other ones [137-141].

\section{Pharmacological therapy}

The muscarinic receptor antagonists, such as atropine, scopolamine (hyoscine), and glycopyrronium bromide inhibit salivary secretion and can, therefore, be employed to treat drooling. These drugs are contraindicated in patients with cardiac problems, glaucoma, prostatic hypertrophy, paralytic ileus, and pyloric obstruction. Results are still incomplete and there are considerable individual variations which can, on occasions, lead to the administration of high doses with the consequent appearances of severe secondary effects such as excessive dry mouth, constipation, urinary retention, blurred vision, irritability, confusion, and even toxic psychosis, all of which are of greater risk to the patient than the sialorrhea itself [15,142].

Atropine when administered sublingually has the capacity to reduce drooling $[143,144]$. Sublingual release has many advantages with respect to via parenteral administration. Atropine is not expensive, does not require special skills for its administration, and has a reversible effect. It is contraindicated in patients with cognitive deterioration, dementia, and hallucinations [14,15].

Scopolamine is applied through transdermal patches (Scopoderm ${ }^{\circledR}$ ) for therapy of nausea associated with motion sickness. Its most common unwanted effect is dry mouth. Scopolamine has been evaluated in patients with drooling, medicated with clozapine, suffering from cerebral lesions, cerebral palsy, or major oropharyngeal resection $[145,146]$. The administration of scopolamine via nebulization provides a better absorption of the drug. An $800 \mu \mathrm{g}$ dose administered two/ three times a day has been reported to be both effective and without side effects [147].

Reviews such as that by Jongerius et al., [148] which studied the efficacy of anticholinergic medication in multi-disabled children, have shown evidence that some anticholinergic medication is effective without preference for any particular one.

\section{Complementary and alternative medicine}

Tongue acupuncture techniques. Acupuncture can stimulate the complex neural network of the tongue thus improving salivary secretion and swallowing mechanisms. Wong et al. [149] observed that it was a treatment without complications, well tolerated by children, and that it markedly improved drooling. Whilst this technique depends a great deal on the skill and experience of the practitioner, it could be an alternative or complementary therapy for children with non-treatable drooling [14]. More longitudinal studies with long-term follow-up and quantitative evaluations are required to determine the validity of this technique.

\section{Radiotherapy}

The application of ionizing radiation for the treatment of sialorrhea, with the aim of decreasing salivary secretion, has been studied by authors such as Borg et al [150]. They warned that radiotherapy in children should be avoided due to the risk of inducing malignancy, delayed growth, xerostomia, mucositis, dental decay, and osteoradionecrosis [150]. This therapy might be effective in specific disorders such as amyotrophic lateral sclerosis, [151] and Parkinson [152].

\section{Minimally invasive methods}

Botulinum toxin injection. Xerostomia is one of the first signs of botulism [14]. Injecting botulinum toxin serotype A causes the inhibition of neuromuscular transmission it acts by blocking the release of acetylcholine neurotransmitter [153]. The pilot studies that have been carried out reported an improvement of the patients treated with the botulinum toxin injection in either both parotid glands or in combination with the submandibular ones $[14,154,155]$. The trial conducted by Lipp et al. [156] concluded that the greater the dose the more reduced the drooling, nevertheless, the optimum dosage has yet to be established.

Botulinum toxin serotype B presents different pharmacological properties, nevertheless, its administration has been shown to be successful in decreasing drooling in patients with Parkinson $[157,158]$.

Photocoagulation of the salivary gland ducts. The concept of laser photocoagulation is based on the partial destruction of the gland and occlusion of the duct. Chang et al. [159] employed the Nd:YAG $(1064 \mathrm{~nm})$ laser for the intra-ductal photocoagulation of both parotid glands. In their study of 48 patients 
with cerebral palsy they reported, in most cases, a significant improvement in drooling with respect to severity and frequency. Postoperatively they observed transient facial swelling in all the patients. The complications were infections, cystic formations, and hematomas, all of which were of low frequency. Photocoagulation of the submandibular gland ducts is reserved for recurrent patients or for those who have had unsatisfactory results from the previously mentioned technique.

\section{Surgical methods}

Surgical control of sialorrhea is the last therapeutical option and is recommended:

- In moderate and persistent cases where conservative therapies have not been successful.

- In severe cases where there are antecedents of failure or limited results from conservative therapies.

- In moderate cases in which there is retarded cognitive development, or where conservative therapies were unsuccessful due to lack of co-operation.

Neurectomy. Sectioning of the parasympathetic nerve reduces the flow of saliva. The tympanic plexus nerve and the tympanic cord may be sectioned, unior bilaterally, either alone or in combination with other procedures such as exeresis of the submandibular gland [160-162]. Neurectomy of the tympanic cord reduces the rates of secretion from the sublingual and submaxillary glands, however, as an isolated procedure results have been shown to be insignificant [163]. Auditory loss could be a possible complication in addition to a decrease in gustative capacity in the anterior two-thirds of the tongue. It is, therefore, not recommended in patients with auditory problems $[14,164]$. Long-term results from isolated neurectomies are controversial $[14,165]$.

Surgical procedures on the salivary duct and gland. The objective of duct ligature is to obtain gland atrophy. There are a number of different procedures which include bilateral ligature of the parotid gland ducts combined with the exeresis of the submandibular glands. This has proven to be the simplest technique with good results (85-86\% success rate) as demonstrated in a total of 96 patients observed in three studies [14,166-168]. Another procedure is repositioning of the parotid gland duct to the tonsillar fossa, or the posterior tonsillar pillar, in order to initiate the swallowing reflex together with a bilateral sialoadenectomy of the submandibular glands $[14,169]$. Repositioning of the submandibular duct carried out alone or combined is a common procedure with a success rate of $75 \%-89 \%$. Advantages include its physiological characteristics and the fact that it is a scar-free technique with few complications. A number of studies have reported differing ductal repositioning techniques and results. It would be of interest to try to relocate the saliva exit towards the base of the tongue in order to physiologically initiate the swallowing reflex [14].

\section{Conclusions}

Quantitative alterations in salivary secretion are frequent in clinical practice. Their prevalence and negative effects on the patient's quality of life oblige the physician to confront the issue.

At present, there are numerous, frequently prescribed drugs whose unwanted effects include some kind of salivary disorder; at the same time there is medication for the clinical management of patients with these symptoms. As a result, the physician may feel disorientated by both the large quantity of trigger or influential factors for these disorders with their differing pathogenic mechanisms, and the great variety of existing treatments.

The pharmacology of most of the substances employed for the treatment of salivary disorders is well-known. Nevertheless, in some cases, depending on the parenchymal gland affection no significant improvement in salivary function has been observed after their administration.

In agreement with the level of scientific evidence which evaluates the various substances employed in the treatment or clinical management of patients with hypersalivation/xerostomia, we can conclude that more clinical studies are needed to evaluate the drugs, substances, and techniques which are presented as useful therapies for these pathologies.

\section{Acknowledgements}

The authors thank Clínics Associats, a well-established Professional Partnership in Terrassa (Barcelona), for its contribution in the publication fees of this manuscript.

\section{Authors' contributions}

JMR and ELS carried out the literature search and selection of manuscripts to be reviewed. JMR, LBL and ELS drafted the article. JMR, LBL, MF revised critically the manuscript for important intellectual content. All the authors read and approved the final manuscript.

\section{Competing Interests}

The authors have declared that no competing interest exists. 


\section{References}

1. Hall JE. Secretory functions of the alimentary tract. In Hall JE, ed. Guyton \& Hall Textbook of Medical Physiology, 12th ed. Philadelphia: Saunders Elsevier; 2011: 773-776.

2. Hector MP, Linden RWA. Reflexes of salivary secretion. In: Garrett JR, Ekstrom J, Anderson LC, eds. Neural Mechanisms of Salivary Gland Secretion. Basel: Karger; 1999:196-217.

3. Melvin JE, Yule D, Shuttleworth T, Begenisich T. Regulation of fluid and electrolyte secretion in salivary gland acinar cells. Ann Rev Physiol. 2005; 67: 445-469.

4. Smith PM. Mechanisms of salivary secretion. In: Edgar M, Dawes C, O'Mullane D, eds. Saliva and Oral Health, 4th ed. London: Stephen Hancocks Ltd; 2012: 17-36.

5. Wong DT. In: Wong DT, ed. Salivary Diagnostics. Iowa: Wiley-Blackwell; 2008: 14-37.

6. Baum BJ, Wellner RB. Receptors in salivary glands. In: Garrett JR, Ekstrom J, Anderson LC, eds. Neural mechanisms of salivary gland secretion. Basel: Karger; 1999: 44-58.

7. Catalán MA, Nakamoto T, Melvin JE. The salivary gland fluid secretion mechanism. J Med Invest. 2009; 56 (Suppl): S192-S196.

8. Humphrey SP, Williamson RT. A review of saliva: Normal composition, flow, and function. J Prosthet Dent. 2001; 85: 162-169.

9. Zolothukin S. Metabolic hormones in saliva: origins and functions. Oral Dis. 2013; 19: 219-229.

10. González A, Rioboo R. El ecosistema bucal. In: Bascones A, ed. Tratado de Odontología. Madrid: Smithkline Beecham; 1998: 2191-2205.

11. Sreebny LM. Saliva in health and diseases: an appraisal and update. Int Dent J. 2000; 50: 140-161.

12. Raspall G. Glandulas salivales In: Raspall G, ed. Cirugía Maxilofacial. Madrid: Ed Médica Panamericana; 2001: 439-466.

13. Freudenreich O. Drug induced sialorrhea. Drugs of Today (Barc). 2005; 41: 411-418.

14. Meningaud JP, Pitak-Arnnop P, Chikhani L, Bertrand JC. Drooling of saliva: A review of the etiology and management options. Oral Surg Oral Med Oral Pathol Oral Radiol Endod. 2006; 101: 48-57.

15. Guggenheimer J, Moore PA. Xerostomia. Etiology, recognition and treatment. J Am Dent Assoc. 2003; 134: 61-69.

16. Villa A, Abati S. Risk factors and symptoms associated with xerostomia: a cross-sectional study. Aus Dent J. 2011; 56: 290-295.

17. Villa A, Polimeni A, Strohmenger L, Cicciù D, Gherlone E, Abati S. Dental patients' self reports of xerostomia and associated risk factors. J Am Dent Assoc. $2011 ; 142: 811-816$

18. Navazesh M, Kumar SK. Xerostomia: prevalence, diagnosis, and management. Compend Contin Educ Dent. 2009; 30: 326-328, 331-334.

19. Grisius MM. Salivary gland dysfunction: A review of systemic therapies. Oral Surg Oral Med Oral Pathol Oral Radiol Endod. 2001; 92: 156-162.

20. Kalf JG, de Swart BJ, Borm GF, Bloem BR, Munneke M. Prevalence and definition of drooling in Parkinson's disease: a systematic review. J Neurol. 2009; 256: 1391-1396

21. Santos MT, Ferreira MC, Leite MF,Guaré RO. Salivary parameters in Brazilian individuals with cerebral palsy who drool. Child Care Health Dev. 2011; 37: 404-409.

22. Hedge AM, Pani SC. Drooling of saliva in children with cerebral palsy etiology, prevalence, and relationship to salivary flow rate in an Indian population. Spec Care Dentist. 2009; 29: 163-168.

23. Tahmassebi JF, Curzon ME. Prevalence of drooling in children with cerebral palsy attending special schools. Dev Med Child Neurol. 2003; 45: 613-617.

24. Ciancio SG. Medications' impact on oral health. J Am Dent Assoc. 2004; 135 : 1440-1448.

25. Nederfors T, Nauntofte B, Twetman S. Effects of furosemide and bendroflumethiazide on saliva flow rate and composition. Arch Oral Biol. 2004; 49: 507-13.

26. Saini-Chohan HK, Hatch GM. Biological actions and metabolism of currently used pharmacological agents for the treatment of congestive heart failure. Curr Drug Metab. 2009; 10: 206-219.

27. Mangrella M, Motola G, Russo F, Mazzeo F, Giassa T, Falcone G, et al. Hospital intensive monitoring of adverse reactions of ACE inhibitors. Minerva Med. 1998; 89: 91-97.

28. Wong KC, Franz DN, Tseng J. Clinical pharmacology of alpha2-agonist and beta-adrenergic blocker. Ma Zui Xue Za Zhi. 1989; 27: 357-362.

29. Zaclikevis MV, D'agulham AC, Bertassoni LE, Machado MA, de Lima AA, Grégio AM, et al. Effects of benzodiazepine and pilocarpine on rat parotid glands: histomorphometric and sialometric study. Med Chem. 2009; 5: 74-78.

30. Titsas A, Ferguson MM. Impact of opioid use in dentistry. Aust Dent J. 2002; 47: 94-98.

31. Graham $\mathrm{CH}$, Meechan JG. Dental management of patients taking methadone. Dent Update. 2005; 32: 477-478，481-482, 485

32. Nathwani NS, Gallagher JE. Methadone: dental risks and preventive action. Dent Update. 2008; 35: 542-4, 547-548.

33. Elad S, Heisler S, Shalit M. Saliva secretion in patients with allergic rhinitis. Int Arch Allergy Immunol. 2006; 141: 276-280.

34. Howell G, West L, Jenkins C, Lineberry B, Yokum D, Rockhold R. In vivo antimuscarinic actions of the third generation antihistaminergic agent, desloratadine. BMC Pharmacology. 2005; 5: 13-25.
35. Gonzalo-Garijo MA, Bobadilla P. Ibuprofen induced fever in Sjogren's syndrome. J Investig Allergol Clin Immunol. 2006; 16: 266-267.

36. Miranda-Rius J, Brunet-Llobet Ll, Lahor-Soler E. Ecstasy (3,4-methylenedioxymethamphetamine, MDMA) related necrotising ulcerative gingivitis. BMJ Case Rep. 2009; doi:10.1136/bcr.06.2008.0290.

37. Schulz-Katterbach M, Imfeld T, Imfeld C. Cannabis and caries -does regular cannabis use increase the risk of caries in cigarette smokers? Schweiz Monatsschr Zahnmed. 2009; 119: 576-583.

38. Vitali C, Bombardieri S, Jonsson R, Moutsopoulos HM, Alexander EL, Carsons $\mathrm{SE}$, et al. Classification criteria for Sjögren's syndrome: a revised version of the European criteria proposed by the American-European Consensus Group. Ann Rheum Dis. 2002; 61: 554-558

39. Daniels TE, Cox D, Shiboski CH, Schiødt M, Wu A, Lanfranchi H, et al. Associations between salivary gland histopathologic diagnoses and phenotypic features of Sjögren's syndrome among 1,726 registry participants. Arthritis Rheum. 2011; 63: 2021-2030.

40. Daniels TE, Whitcher JP. Association of patterns of labial salivary gland inflammation with keratoconjunctivitis sicca: analysis of 618 patients with suspected Sjögren's syndrome. Arthritis Rheum. 1994; 37: 869-877.

41. Shiboski SC, Shiboski CH, Criswell L, Baer A, Challacombe S, Lanfranchi H, et al. American College of Rheumatology classification criteria for Sjögren's Syndrome: a data-driven, expert consensus approach in the Sjögren's International Collaborative Clinical Alliance cohort. Arthritis Care Res (Hoboken). 2012; 64: 475-487.

42. Daniels TE, Criswell LA, Shiboski C, Shiboski S, Lanfranchi H, Dong Y, et al. An early view of the International Sjögren's Syndrome Registry. Arthritis Rheum. 2009; 61: 711-714.

43. Trotti A. Toxicity in head and neck cancer: a review of trends and issues. Int J Radiat Oncol Biol Phys. 2000; 47: 1-12.

44. Chambers MS, Garden AS, Kies MS, Martin JW. Radiation-induced xerostomia in patients with head and neck cancer: pathogenesis, impact in quality of life, and management. Head Neck. 2004; 26: 796-807.

45. Cooper JS, Fu K, Marks J, Silverman S. Late effects of radiation therapy in the head and neck region. Int J Radiat Oncol Biol Phys. 1995; 31: 1141-1164.

46. Dirix P, Nuyts $S$, van den Bogaert W. Radiation-induced xerostomia in patients with head and neck cancer: a literature review. Cancer. 2006; 107: 2525-2534.

47. Franzén L, Funegård U, Ericson T, Henriksson R. Parotid gland function during and following radiotherapy of malignancies in the head and neck. A consecutive study of salivary flow and patient discomfort. Eur J Cancer. 1992; 28: $457-462$.

48. Scrimger R. Salivary gland sparing in the treatment of head and neck cancer. Expert Rev Anticancer Ther. 2011; 11: 1437-1448.

49. Gorsky M, Epstein JB, Parry J, Epstein MS, Le ND, Silverman S Jr. The efficacy of pilocarpine and bethanechol upon saliva production in cancer patients with hyposalivation following radiation therapy. Oral Surg Oral Med Oral Pathol Oral Radiol Endod. 2004; 97: 190-195.

50. Steele LS, Glazier RH. Is donezepil effective for treating Alzheimer's disease? Can Fam Physician. 1999; 45: 917-919.

51. Scott LJ, Goa KL. Galantamine a review of its use in Alzheimer's disease. Drugs. 2000; 60: 1095-1122.

52. Finkel SI. Effects of rivastigmine on behavioural and psychological symptoms of dementia in Alzheimer's disease. Clin Ther. 2004; 26: 980-990.

53. Drachman DB. Myasthenia gravis. N Engl J Med. 1994; 330: 1797-1810.

54. Szabadi E. Clozapine-induced hypersalivation. Br J Psychiatry. 1997; 171: 89.

55. Corrigan FM, McDonald S, Reynolds GP. Clozapine-induced hypersalivation and the alpha 2 adrenoceptor. Br J Psychiatry. 1995; 167: 412.

56. Kales SN, Christiani DC. Acute chemical emergencies. N Engl J Med. 2004; 350: 800-808

57. Brown JS Jr. Environmental and chemical toxins and psychiatric illness. Washington DC: American Psychiatric Publishing, Inc. 2002.

58. Doherty MJ. The quicksilver price. Mercury vapor poisoning aboard HMS Triumph and HMS Phipps. Neurology. 2004; 62: 963-966.

59. Clarkson TW, Magos L, Myers GJ. The toxicology of mercury - Current exposures and clinical manifestations. N Eng J Med. 2003; 349: 1731-1737.

60. Solis MT, Yuen E, Cortez PS, Goebel PJ. Family poisoned by mercury vapor inhalation. Am J Emerg Med. 2000; 18: 599-602.

61. Bagheri H, Schmitt L, Berlan M, Montastruc JL. Effect of 3 weeks treatment with yohimbine on salivary secretion in healthy volunteers and in depressed patients treated with tricyclic antidepressants. Br J Clin Pharmacol. 1992; 34: 555-558.

62. Palmer JB, Drennan JC, Baba M. Evaluation and treatment of swallowing impairments. Am Fam Physician. 2000; 61: 2453-2462.

63. Nunn JH. Drooling: review of the literature and proposals for management. J Oral Rehabil. 2000; 27: 735-743.

64. Lespargot A, Langevin MF, Muller S, Guillemont S. Swallowing disturbances associated with drooling in cerebral palsied children. Dev Med Child Neurol. 1993; 35: 298-304.

65. Fox PC. Salivary enhancement therapies. Caries Res. 2004; 38: 241-246.

66. Atkinson JC, Grisius M, Massey W. Salivary hypofunction and xerostomia: diagnosis and treatment. Dent Clin North Am. 2005; 49: 309-326.

67. Sreebny LM, Schwartz SS. A reference guide to drugs and dry mouth. Gerodontology. 1986; 5: 75-99.

68. Byrne BE. Oral manifestations of systemic agents. In: ADA guide to dental therapeutics. Chicago: ADA Publishing; 1998: 469-475. 
69. von Bültzinglöwen I, Sollecito TP, Fox PC, Daniels T, Jonsson R, Lockhart PB, et al. Salivary dysfunction associated with systemic diseases: systematic review and clinical management recommendations. Oral Surg Oral Med Oral Pathol Oral Radiol Endod. 2007; 103 (Suppl): S57.e1-15.

70. Fox PC, van der Ven PF, Baum BJ, Mandel ID. Pilocarpine for the treatment of xerostomia associated with salivary gland dysfunction. Oral Surg Oral Med Oral Pathol. 1986; 61: 243-248.

71. Valdez IH, Wolff A, Atkinson JC, Macynski AA, Fox PC. Use of pilocarpine during head and neck radiation therapy to reduce xerostomia and salivary dysfunction. Cancer. 1993; 71: 1848-1851.

72. [Internet] http://dailymed.nlm.nih.gov/dailymed/drugInfo.cfm?setid= 16b10412-0031-4e7b-b510-99ae89b138e5

73. Fife RS, Chase WF, Dore RK, Wiesenhutter CW, Lockhart PB, Tindall E, Suen JY. Cevimeline for the treatment of xerostomia in patients with Sjögren syndrome. Arch Intern Med. 2002; 162: 1293-1300.

74. Petrone D, Condemi JJ, Fife R, Gluck O, Cohen S, Dalgin P. A double-blind, randomized, placebo-controlled study of cevimeline in Sjögren's syndrome patients with xerostomia and keratoconjunctivitis sicca. Arthritis Rheum. 2002; 46: 748-754.

75. Weber J, Keating GM. Cevimeline. Drugs. 2008; 68: 1691-1698.

76. Everett HC. The use of bethanechol chloride with tricyclic antidepressants. Am J Psychiatry. 1975; 132: 1202-1204.

77. Schubert DS. The use of bethanechol chloride with phenothiazines: a case report. Am J Psychiatry. 1979; 136: 110-111.

78. [Internet] http://dailymed.nlm.nih.gov/dailymed/drugInfo.cfm?setid= 5513ddc8-90c8-4548-8188-5a807465cdc4

79. Epstein JB, Decoteau WE, Wilkinson A. Effect of Sialor in treatment of xerostomia in Sjögren's syndrome. Oral Surg Oral Med Oral Pathol. 1983; 56: 495-499.

80. Schiødt M, Oxholm P, Jacobsen A. Sulfarlem S25 in the treatment of primary Sjögren's syndrome. Scand J Rheumatol. 1986; 61: 250-252.

81. Almståhl A, Wikström M, Stenberg I, Jakobsson A, Fagerberg-Mohlin B. Oral microbiota associated with hyposalivation of different origins. Oral Microbiol Immunol. 2003; 18: 1-8.

82. Ramos-Casals M, Brito-Zerón P. Emerging biological therapies in primary Sjögren's syndrome. Rheumatology (Oxford). 2007; 46: 1389-1396.

83. Grisius MM, Bermudez DK, Fox PC. Salivary and serum interleukin 6 in primary Sjögren's syndrome. J Rheumatol. 1997; 24: 1089-1091.

84. Shiozawa S, Morimoto I, Tanaka Y, Shiozawa K. A preliminary study of the interferon-alpha treatment for xerostomia of Sjögren's syndrome. Br J Rheumatol. 1993; 32: 52-54.

85. Shiozawa S, Tanaka Y, Shiozawa K. Single-blinded controlled trial of low dose oral IFN-alpha for the treatment of Sjögren's syndrome. J Interferon Cytokine Res. 1998; 18: 255-262.

86. Ship JA, Fox PC, Michalek JE, Cummins MJ, Richards AB. Treatment of primary Sjögren's syndrome with low-dose natural human interferon-alpha administered by the oral mucosal route: a phase II clinical trial. IFNprotocol study group. J Interferon Cytokine Res. 1999; 19: 943-951.

87. Ferraccioli GF, Salaffi F, de Vita S, Casatta L, Avellini C, Carotti M, et al. Interferon alpha-2 (IFN alpha 2) increases lacrimal and salivary function in Sjögren's syndrome patients. Preliminary results of an open pilot trial versus OH-chloroquine. Clin Exp Rheumatol. 1996; 14: 367-371.

88. Devauchelle-Pensec V, Pennec Y, Morvan J, et al. Improvement of Sjögren's syndrome after two infusions of rituximab (anti-CD20). Arthritis Rheum. 2007; 57: 310-317.

89. Pijpe J, van Imhoff GW, Spijkervet FK, Roodenburg JL, Wolbink GJ, Mansour $\mathrm{K}$, et al. Rituximab treatment in patients with primary Sjögren's syndrome: an open-label phase II study. Arthritis Rheum. 2005; 52: 2740-2750.

90. Meijer JM, Meiners PM, Vissink A, Spijkervet FK, Abdulahad W, Kamminga $\mathrm{N}$, et al. Effectiveness of Rituximab Treatment in Primary Sjögren's Syndrome. Arthritis Rheum. 2010; 62: 960-968.

91. Meiners PM, Vissink A, Kallenberg CG, Kroese FG, Bootsma H. Treatment of primary Sjögren's syndrome with anti-CD20 therapy (rituximab). A feasible approach or just a starting point? Expert Opin Biol Ther. 2011; 11: 1381-1394.

92. Ramos-Casals M, Tzioufas AG, Stone JH, Sisó A, Bosch X. Treatment of primary Sjögren syndrome: a systematic review. JAMA. 2010; 304: 452-460.

93. Manoussakis MN, Moutsopoulos HM. Antimalarials in Sjögren's syndrome the Greek experience. Lupus. 1996; 5 (Suppl1): S28-S30.

94. Fox RI, Dixon R, Guarassi V, Krubel S. Treatment of primary Sjögren's syndrome hydroxychloroquine: a retrospective, open-label study. Lupus. 1996; 5 (Suppl1):S31-S36.

95. Fox PC, Datiles M, Atkinson JC, Macynski AA, Scott J, Fletcher D, et al. Prednisone and piroxicam for treatment of primary Sjögren's syndrome. Clin Exp Rheumatol. 1993; 11: 149-156.

96. Skopouli FN, Jagiello P, Tsifetaki N, Moutsopoulos HM. Methotrexate in primary Sjögren's syndrome. Clin Exp Rheumatol. 1996; 14: 555-558.

97. Moerman RV, Bootsma H, Kroese FG, Vissink A. Sjögren's syndrome in older patients: aetiology, diagnosis and management. Drugs Aging. 2013; 30: $137-153$

98. Adler S, Körner M, Förger F, Huscher D, Caversaccio MD, Villiger PM. Evaluation of histologic, serologic, and clinical changes in response to abatacept treatment of primary Sjögren's syndrome: a pilot study. Arthritis Care Res (Hoboken) 2013; 65: 1862-1868.

99. Fox PC. Salivary enhancement therapies. Caries Res. 2004; 38: 241-246.
100. Itthagarum A, Wei SH. Chewing gum and saliva in oral health. J Clin Dent. 1997; 8: 159-162

101. Simons D, Kidd EA, Beighton D, Jones B. The effect of chlorhexidine/xylitol chewing-gum on cariogenic salivary microflora: a clinical trial in elderly patients. Caries Res. 1997; 31: 91-96.

102. Makin SA. Stannous fluoride dentifrices. Am J Dent. 2013; 26 (Spec No A): AA-9A.

103. Nordström A, Birkhed D. preventive effect of high-fluoride dentifrice $(5,000$ ppm) in caries-active adolescents: a 2-year clinical trail. Caries Res. 2010; 44: 323-331.

104. Nieuw Amerogen AV, Veerman EC. Current therapies for xerostomia and salivary gland hypofunction associated with cancer therapies. Support Care Cancer. 2003; 11: 226-231.

105. Bots CP, Brand HS, Veerman EC, Korevaar JC, Valentijn-Benz M, Bezemer PD, et al. Chewing gum and a saliva substitute alleviate thirst and xerostomia in patients on haemodialysis. Nephrol Dial Transplant. 2005; 20: 578-584.

106. Sweeney MP, Bagg J, Baxter WP, Aitchison TC. Clinical trial of a mucin-containing oral spray for treatment of xerostomia in hospice patients. Palliat Med. 1997; 11: 225-232.

107. Ship JA, Mc Cutcheon JA, Spivakovsky S, Kerr AR. Safety and effectiveness of topical dry mouth products containing olive oil, betaine, and xylitol in reducing xerostomia for polypharmacy-induced dry mouth. J Oral Rehabil. 2007; 34: 724-732

108. Stewart CM, Iones AC, Bates RE, Sandow P, Pink F, Stillwell J. Comparison between saliva stimulants and a saliva substitute in patients with xerostomia and hyposalivation. Spec Care Dentist. 1998;18: 142-148.

109. Frost PM, Shirlaw PJ, Walter JD, Challacombe SJ. Patient preferences in a preliminary study comparing an intra-oral lubricating device with the usual dry mouth lubricating methods. Br Dent J. 2002; 193: 403-408.

110. Robinson PG, Pankhurst CL, Garrett EJ. Randomized-controlled trial: effect of a reservoir biteguard on quality of life in xerostomia. J Oral Pathol Med. 2005; 34:193-197.

111. Frost PM, Shirlaw PJ, Challacombe SJ, Fernandes-Naglik L, Walter JD, Ide M. Impact of wearing an intra-oral lubricating device on oral health in dry mouth patients. Oral Dis. 2006; 12: 57-62.

112. McMillan AS, Tsang CS, Wong MC, Kam AY. Efficacy of a novel lubricating system in the management of radiotherapy-related xerostomia. Oral Oncol. 2006; 42: 842-848

113. Lafaurie G, Fedele S, López RM, Wolff A, Strietzel F, Porter SR, et al. Avances biotecnológicos en la neuroelectroestimulación para el tratamiento de la hiposalivación y la xerostomia. Med Oral Patol Oral Cir Bucal. 2009; 14: E76-E80.

114. Carramolino E, Silvestre FJ. Boca seca y su manejo en la clínica odontológica. Dentum. 2009; 9: 24-31.

115. Strietzel FP, Martín-Granizo R, Fedele S, Lo Russo L, Mignogna M, Reichart PA, Wolff A. Electroestimulating device in the management of xerostomia. Oral Dis. 2007; 13: 206-213.

116. Hargitai IA, Sherman RG, Strother JM. The effects of electrostimulation on parotid saliva flow: a pilot study. Oral Surg Oral Med Oral Pathol Oral Radiol Endod. 2005; 99: 316-320

117. Alajbeg I, Falcão DP, Martín-Granizo R, Lafaurie GI, Matranga D, Pejda S, et al. Intraoral electrostimulator for xerostomia relief: a long-term, multicenter, open-label, uncontrolled, clinical trial. Oral Surg Oral Med Oral Pathol Oral Radiol. 2012; 113: 773-781.

118. Baum BJ, Alevizos I, Zheng C, Cotrim AP, Liu S, McCullagh L, et al. Early responses to adenoviral-mediated transfer of the aquaporin- 1 cDNA for radiation-induced salivary hypofunction. Proc Natl Acad Sci USA. 2012 109: 19403-19407.

119. Baum BJ. Gene therapy. Oral Dis. 2014; 20: 115-118.

120. Kagami H, Wang S, Hai B. Restoring the function of salivary glands. Oral Dis. 2008; $14: 15-24$

121. Purnell B. The complete guide to organ repair Science. 2008· 322. 1489.

122. Sasai Y. Next-generation regenerative medicine: organogenesis from stem cells in 3D culture. Cell Stem Cell. 2013; 12: 520-530.

123. Takahashi S, Schoch E, Walker NI. Origin of acinar cell regeneration after atrophy of the rat parotid induced by duct obstruction. Int J Exp Pathol. 1998; 79: 293-301.

124. Ogawa M, Oshima M, Imamura A, Sekine Y, Ishida K, Yamashita K, et al. Functional salivary gland regeneration by transplantation of a bioengineered organ germ. Nat Commun. 2013; 4: 2498

125. Jha N, Seikaly H, Harris J, Williams D, Liu R, McGaw T, et al. Prevention of radiation induced xerostomia by surgical transfer of submandibular salivary gland into the submental space. Radiother Oncol. 2003; 66: 283-289.

126. Jha N, Seikaly H, McGaw T, Coulter L. Submandibular salivary gland transfer prevents radiation induced xerostomia. Int J Radiat Oncol Biol Phys. 2000; 46: $7-11$.

127. Seikaly H, Jha N, McGaw T, Coulter L, Liu R, Oldring D. Submandibular gland transfer: a new method of preventing radiation induced xerostomia. Laryngoscope. 2001; 111: 347-352.

128. Vissink A, van Luijk P, Langendijk J, Coppes R. Current ideas to reduce or salvage radiation damage to salivary glands. Oral Dis. 2014; [Epub ahead of Print].

129. Bagheri H, Schmitt L, Berlan M, Montastruc JL. A comparative study of the effects of yohimbine and anetholtrithione on salivary secretion in depressed 
patients treated with psychotropic drugs. Eur J Clin Pharmacol. 1997; 52: 339-342.

130. Pedersen A, Gerner N, Palmvang I, Hoier-Madsen M. LongoVital in the treatment of Sjögren's syndrome. Clin Exp Rheumatol. 1999; 5: 533-538.

131. Kempe C, Gruning H, Stasche N, Hormann K. Icelandic moss lozenges in the prevention or treatment of oral mucosa irritation and dried out throat. Laryngo Rhino Otologie. 1997; 3: 186-188.

132. Kagami H, Horie $\mathrm{K}$, Nishiguchi $\mathrm{H}$, Shigetomi T, Ueda M. Effect of bakumondo-to, a Chinese-Japanese herbal medicine, on cultures and dispersed salivary gland cells. J Ethnopharmacol. 1996; 2: 89-95.

133. Jedel E. Acupuncture in xerostomia - a systematic review. J Oral Rehabil. 2005; 32: 392-396.

134. Dawidson I, Angmar-Månsson B, Blom M, Theodorsson E, Lundeberg T. Sensory stimulation (acupuncture) increases the release of vasoactive intestinal polypeptide in the saliva of xerostomia sufferers. Neuropeptides. 1998; 32: 543-548.

135. Dawidson I, Angmar-Månsson B, Blom M, Theodorsson E, Lundeberg T. Sensory stimulation (acupuncture) increases the release of calcitonin gene-related peptide in the saliva of the xerostomia sufferers. Neuropeptides. 1999; 33: 244-250.

136. Koheil R, Sochaniwsky A, Bablich K, Kenny DJ, Milner M. Biofeedback techniques and behaviour modification in the conservative remediation of drooling by by children with cerebral palsy. Dev Med Child Neurol. 1987; 29: 19-26.

137. Hoyer H, Limbrock GJ. Orofacial regulation therapy in children with Down syndrome, using the method and appliances of Castillo-Morales. ASDC J Dent Child. 1990; 57: 442-444.

138. Limbrock GJ, Hoyer H, Scheying H. Regulation therapy by Castillo-Morales in children with Down's syndrome: primary and secondary orofacial pathology. ASDC J Dent Child. 1990; 57: 437-441.

139. de Serpa Pinto MV, de Magalhães MH, Nunes Fd. Moebius syndrome with oral involvement. Int J Paediatr Dent. 2002; 12: 446-449.

140. Limbrock GJ, Fischer-Brandies H, Avalle C. Castillo-Morales orofacial therapy: treatment of 67 children with Down syndrome. Dev Med Child Neurol. 1991; 33: 296-303.

141. Limbrock GJ, Hoyer H, Scheying H. Drooling, chewing and swallowing dysfunctions in children with cerebral palsy: treatment according to Castillo-Morales. ASDC J Dent Child. 1990; 57: 445-451.

142. Sennhauser FH, Schwarz HP. Toxic psychosis from transdermal scopolamine in a child. Lancet. 1986; 2: 1033.

143. Hyson $\mathrm{CH}$, Johnson AM, Jog MS. Sublingual atropine for sialorrhea secondary to Parkinsonism: a pilot study. Mov Disord. 2002; 17: 1318-1320.

144. Comley C, Galletley C, Ash D. Use of atropine eye drops for clozepine-induced hypersalivation. Aust N Z J Psychiatry. 2000; 34: 1033-1034.

145. Gaftanyuk O, Trestman RL. Scopolamine patch for clozepine induced sialorrhea. Psychiatr Serv. 2004; 55: 318

146. Dreyfuss P, Vogel D, Walsh N. The use of transdermal scopolamine to control drooling. A case report. Am J Phys Med Rehabil. 1991; 70: 220-222.

147. Zeppetella G. Nebulized scopolamine in the management of oral dribbling: three case reports. J Pain Symptom Manage. 1999; 17: 293-295.

148. Jongerius PH, vanTiel P, van Limbeek J, Gabreëls FJ, Rotteveel JJ. A systematic review for evidence of efficacy of anticholinergic drugs to treat drooling. Arch Dis Child. 2003; 88: 911-914.

149. Wong V, Sun JG, Wong W. Traditional Chinese medicine (tongue acupuncture) in children with drooling problems. Pediatr Neurol. 2001; 25: 47-54.

150. Borg M, Hirst F. The role of radiation therapy in the management of sialorrhea. Int J Radiation Oncol Biol Phys. 1998; 41: 1113-1119.

151. Assouline A, Levy A, Abdelnour-Mallet M, Gonzalez-Bermejo J, Lenglet T, Le Forestier N, et al. Radiation therapy for hypersalivation: a prospective study in 50 amyotrophic lateral sclerosis patients. Int J Radiat Oncol Biol Phys. 2014; 88: 589-595.

152. Perez Lloret S, Rey MV, Pavy-Le Traon A, Rascol O. Emerging drugs for autonomic dysfunction in Parkinson's disease. Expert Opin Emerg Drugs. 2013; 18: 39-53.

153. Breidenbach MA, Brunger AT. Substrate recognition strategy for botulinum neurotoxin serotype A. Nature. 2004; 432: 925-929.

154. Mancini F, Zangaglia R, Cristina S, Sommaruga MG, Martignoni E, Nappi G, et al. Double-blind, placebo-controlled study to evaluate the efficacy and safety of botulinum toxin type A in the treatment of drooling in parkinsonism. Mov Disord. 2003; 18: 685-688.

155. Dogu O, Apaydin D, Sevim S, Talas DU, Aral M. Ultrasound guided versus blind intraparotid injections of botulinum toxin- $\mathrm{A}$ for the treatment of sialorrhoea in patients with Parkinson's disease. Clin Neurol Neurosurg. 2004; 106: 93-96.

156. Lipp A, Trottenberg T, Schink T, Kupsch A, Arnold G. A randomized trial of botulinum toxin A for treatment of drooling. Neurology. 2003; 61: 1279-1281.

157. Racette BA, Good L, Sagitto S, Perlmutter JS. Botulinum toxin B reduces sialorrhea in Parkinsonism. Mov Disord. 2003; 18: 1059-1061.

158. Ondo WG, Hunter C, Moore W. A double-blind placebo-controlled trial of botulinum toxin B for sialorrhea in Parkinson's disease. Neurology. 2004; 62: $37-40$.

159. Chang CJ, May-Kuen Wong AA. Intraductal laser photocoagulation of the bilateral parotid ducts for reduction of drooling in patients with cerebral palsy. Plast Reconstr Surg. 2001; 107: 907-913.

160. Arnold HG, Gross CW. Transtympanic neurectomy: a solution to drooling problems. Dev Med Child Neurol. 1977; 19: 509-513.
161. Mullins WM, Gross CW, Moore JM. Long-term follow-up of tympanic neurectomy for sialorrhea. Laryngoscope. 1979; 89: 1219-1223.

162. Sellars SL. Surgery of sialorrhoea. J Laryngol Otol. 1985; 99: 1107-1109.

163. Grewal DS, Hiranandani NL, Rangwalla ZA, Sheode JH. Transtympanic neurectomies for control of drooling. Auris Nasus Larynx. 1984; 11: 109-114.

164. Grant R, Miller S, Simpson D, Lamey PJ, Bone I. The effect of chorda tympani section on ipsilateral and contralateral salivary secretion and taste in man. J Neurol Neurosurg Psychiatry. 1989; 52: 1058-1062.

165. Parisier SC, Blitzer A, Binder WJ, Friedman WF, Marovitz WF. Tympanic neurectomy and chorda tympanectomy for the control of drooling. Arch Otolaryngol. 1978; 104: 273-277.

166. Dundas DF, Peterson RA. Surgical treatment of drooling by bilateral parotid duct ligation and submandibular gland resection. Plast Reconstr Surg. 1979; 64: 47-51.

167. Shott SR, Myer CM, Cotton RT. Surgical management of sialorrhea. Otolaryngol Head Neck Surg. 1989; 101: 47-50.

168. Brundage SR, Moore WD. Submandibular gland resection and bilateral parotid duct ligation as a management of chronic drooling in cerebral palsy. Plast Reconstr Surg. 1989; 83: 443-446.

169. Wilkie TF. The problem of drooling in cerebral palsy: a surgical approach. Can J Surg. 1967; 10: 60-67. 